\title{
Vulkansk aktivitet på Jorden - nyt fra de sidste 6 måneder
}

Af geolog Susanne Plesner, GeologiskNyt

Denne opdatering sætter ekstra fokus på russiske vulkaner - specielt stratovulkanen Karymsky, der har været aktiv i et stykke tid.

Flere af vulkanerne i Indonesien samt Etna på Sicilien og Kilauea på Hawaii har flere gange i løbet af foråret haft pressens interesse. Kamchatka er igen for alvor kommet på banen med aktivitet fra ikke mindre end seks vulkaner, hvilket er fire mere end det foregående halvår. Den manglende interesse fra verdenspressen skyldes jo nok den afsides beliggenhed for det meste af civilisation. Det vil vi i dette nummer forsøge at råde lidt bod på ved overordnet at fortælle lidt mere om dem.

Vulkanen Fourpeaked i Alaska, som tidligere gjorde en del væsen af sig, synes derimod at være sygnet lidt hen igen. I hvert fald har den ikke budt på spændende nyt siden oktober 2006.

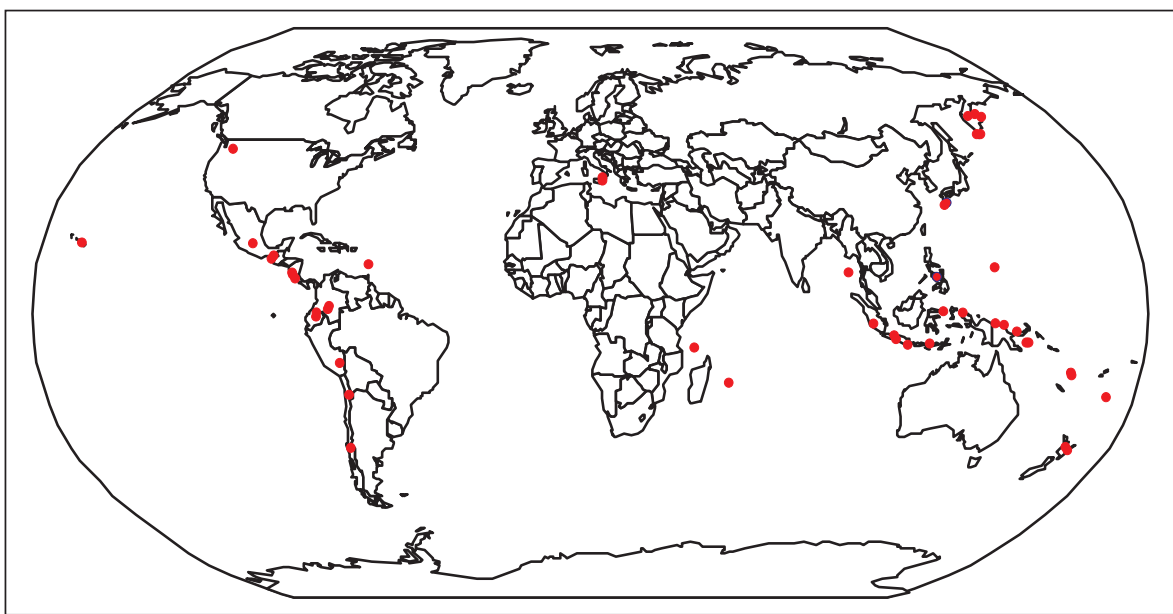

Verdenskort, der med røde fyldte cirkler viser fordelingen af den vulkanske aktivitet de seneste seks måneder. (Grafik: Forfatteren)

Vulkanerne på Kamchatka

Kamchatka-halvøen udgør et af de mest aktive vulkanske områder i den pacifiske

"Ring of Fire". Her findes mere end 100 vulkaner, hvoraf de fleste er fordelt langs østkysten af halvøen. Omkring et dusin af dem har været aktive de senere år.

Næsten samtlige af de i øjeblikket mest

\section{Vulkansk aktivitet de sidste 6 måneder}

Nordlige Stillehavsregion

Kilauea, Hawaii, USA

St. Helens, Washington, USA

Anathan, Marianer Øerne, USA

Suwanose-Jima, Ryukyu Øerne, Japan

Sakura-Jima, Kyushu, Japan

Bulusan, Filippinerne

Dukono, Halmahera, Indonesien

Karangetang, Indonesien

Sydlige Stillehavsregion

Semeru, Java, Indonesien

Merapi, Java, Indonesien

Talang, Sumatra, Indonesien

Batu Tara, Indonesien

Slamet, Indonesien

Bagana, Papua Ny Guinea

Langila, Papua Ny Guinea

Rabaul, Papua Ny Guinea

Ulawun, Papua Ny Guinea

Manam, Papua Ny Guinea

Ritter Island, Papua Ny Guinea

Lopevi, Vanuatu

Ambrym, Vanuatu
White Island, New Zealand

Ruapehu, New Zealand

Home Reef, Tonga

Mellemamerika, Mexico, Vestindien

Telica, Nicaragua

Concepción, Nicaragua

Arenal, Costa Rica

Turrialba, Costa Rica

Colima, Mexico

Popocatépetl, Mexico

Fuego, Guatemala

Santa María, Guatemala

Pacaya, Guatamala

Soufriere Hills, Montserrat

Sydamerika
Tungurahau, Ecuador
Sangay, Ecuador
Reventador, Ecuador
Galeras, Colombia
Nevado del Huila, Colombia
Lascar, Chile
Llaima, Chile

Ubinas, Peru

Rusland

Karymsky, Kamchatka

Shiveluch, Kamchatka

Kliuchevskoi, Kamchatka

Bezymianny, Kamchatka

Chikurachki, Kurillerne

Ebeko, Kurillerne

Indiske Ocean

Piton de la Fournaise, Réunion

Barren Island, Indien

Karthala, Comoro Øerne

Afrika

Nyamuragira, Demokratiske Republik Congo

Europa

Etna, Italien

Stomboli, Italien 


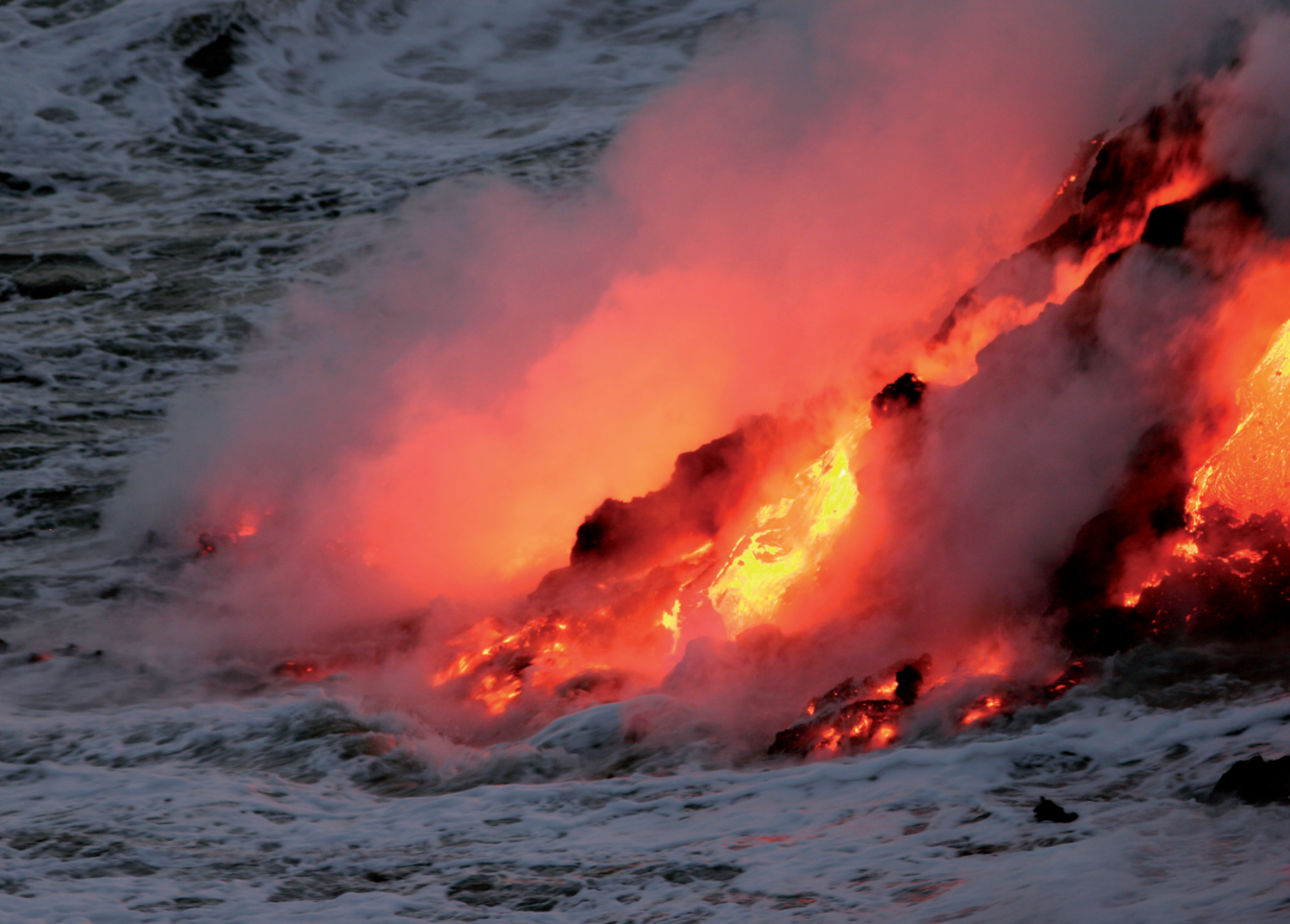

Kilanea i udbrud på Hawaii. På billedet ses lavastroemme, som flyder ud i havet og danner nyt land. (Foto: Tom Pfeiffer, april 2007)

aktive og mest kendte vulkaner er stratovulkaner. De mindre kendte tæller endvidere en del skjoldvulkaner, cinder-kegler og nogle enkelte sammensatte vulkaner.

Udbrudsprodukterne er typisk af basaltisk eller andesitisk sammensætning. Den vulkanske aktivitet er i øjeblikket meget præget af strombolianske udbrud eller af væksten af lavadomer inde i vulkanerne, som oftest ender med at kollapse relativt fredeligt. Der har dog i holocæn tid (og også før dette) været en del relativt eksplosive udbrud, hvor dele af toppen af den enkelte vulkan er blevet sprængt væk, som man fx så det ved Mt. St. Helens i USA i 1980. Pyroklastiske strømme er heller ikke ualmindelige, men udbredelsen af dem er ikke stor.

Den meste aktive vulkan på Kamchatka i øjeblikket er Karymsky, der er en 1.536 m høj, symmetrisk formet stratovulkan med en topcaldera på $5 \mathrm{~km}$ i diameter. Vulkanens dannelse begyndte for ca. 7.500 år siden, og den seneste aktive periode begyndte for 500 år siden. Inden dette var vulkanen inaktiv i ca. 2.300 år. Det meste af vulkankeglen er i dag dækket af lavastrømme, der er mindre end 200 år gamle - altså fra den igangværende aktive periode. Aktiviteten i indeværende periode har primært været af stromboliansk karakter og altså ikke voldsomt eksplosiv.

Relevante links:

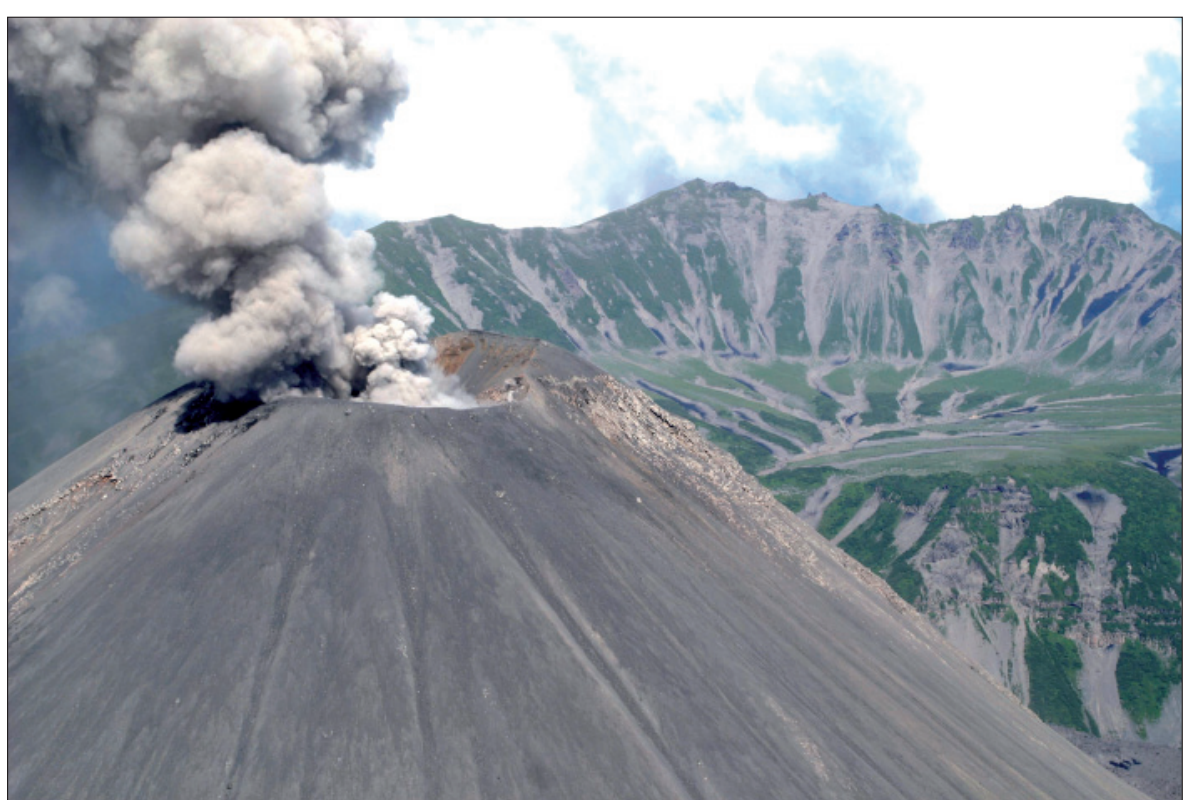

Vulkanen Karymsky i udbrud - dette billede stammer fra juli 2006 (i øvrigt "Månedens billede" i nr. 1-2007). (Foto: Eigil Holm) http://www.volcano.si.edu/reports/usgs/index.cfm? content $=$ archive http://volcano.und.nodak.edu/ 